\title{
Hayvan Odaklı Turizm Faaliyetlerine Meta Eleştirel Bakış: Türkiye Örneği ${ }^{1}$
}

\author{
A Meta Critical Review of Animal-Based Tourism Activities: Case of Turkey
}

\author{
S. Emre DiLEK*, Ebru GÜNLÜ KÜÇÜKALTAN** \\ *Yrd. Doç. Dr., Batman Üniversitesi Turizm İşletmeciliği ve Otelcilik Yüksekokulu, Gastronomi ve Mutfak Sanatları Bölümü, 72160, Batı Raman Kampüsü, Batman. \\ E-posta: s.emre.d@hotmail.com \\ ORCID: 0000-0001-7830-1928 \\ **Prof. Dr., Dokuz Eylül Üniversitesi İşletme Fakültesi, Turizm İşletmeciliği Bölümü, 35390, Tınaztepe Kampüsü, İzmir. \\ E-posta: ebru.gunlu@deu.edu.tr \\ ORCID: 0000-0003-2599-0197
}

MAKALE BILGILERI

Makale işlem bilgileri:

Gönderilme tarihi: 19 Nisan 2017

Düzeltme: 21 Haziran 2017

Düzeltme: 24 Temmuz 2017

Kabul: 26 Temmuz 2017

Anahtar sözcükler: Metalaştırılmış hayvanlar, Turizm ve hayvan etiğ i, Turist-hayvan ilişkisi.

\section{ARTICLE INFO}

Article history:

Submitted: 19 April 2017

Resubmitted: 21 June 2017

Resubmitted: 24 July 2017

Accepted: 26 July 2017

Key words: Commoditised animals, Tourism and animal ethics, Touristanimal relationships.
ÖZ Çalışmanın konusu, turizm sektöründe hayvanların metalaştıııldığı alanları ortaya koyarak, eleștirel bir tahlil yapmaktadır. Bu bağlamda çalışma-
nın amacı, turizmin hayvanlara yönelik ahlaki sorumluluğunu tartışmaya açarak, öneriler geliștirmektir. Bu tür bir çalıșma, Türkiye'de turizm yazlnın amacı, turizmin hayvanlara yonelik ahlaki sorumluluğunu tartışmaya açarak, oneriler geliștirmektir. Bu tư bir çalışma, Turkiye' de turizm yazlnında bulunmamakta olup, bu yönüyle ilk olma özelliğini taşımaktadır. Çalışmada, turizmin hem arz hem de talep boyutunda hayvanlara yönelik
nasıl bir ahlaki sorumluluğa sahip olması gerektiğ́i üzerinde bir tartıșma yürütülmektedir. Türkiye'de yer alan toplam 23 hayvan odaklı turizm ișlet-

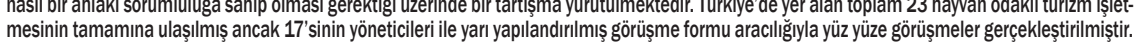
mesinin tamamına ulaşıımış ancak 17'sinin yöneticileri ile yarı yapılandırılmış görüssme formu aracilığıly yüz yüze görüşmeler gerçekleştirilmiștir. Söz konusu ișletmelere gelen ziyaretçiler ise kolayda örneklem yöntemi ile seçilmiş olup katllımcılara uygulanan anketlerden toplam 406 adet geri
dönüşs sağlanmış ve 388'i analize dâhil edilmiştir. Yüz yüze göruşşmeler yoluyla elde edilen veriler betimsel analiz ile anket yoluyla elde edilen veriler dönüş sağlanmış ve 388'i analize dâhil edilmişțir. Yüz yüze görüşmmeler yoluyla elde edilen veriler betimsel analiz ile anket yoluyla elde edilen veriler ișletmelerini ziyaret edenlerin demografik özellikleri, verdikleri yanıtların YEM aracilı̆̆glyla oluşturulan modellemesi ile ișletme yöneticilerinin hayvanların metalaștııımasına ilişkin verdikleri yanıtlar karşılaştırmalı olarak ele alınmıștı. Ziyaretçiler kendilerini daha çok ekosentrik olarak ifade etseler de hayvan odaklı çekiciliklere katılım amaçlarını "doğa turizmine bir alternatif", "eğitim aracı" ve "aile odaklı deneyim" șeklinde belirterek antroposentrik bir duruș ortaya koymaktadırlar. ișletme yöneticilerinin verdikleri yanıtlar ise (1) mevcut durum, (2) etik durum, (3) diș çevre ana temaları altında toplanmış olup, genel olarak hayvanlara yönelik ahlaki ve yasal sorumluluktan uzak oldukları sonucuna varılmıștır. Bu yönüyle hem arz hem de talep boyutunda, hayvanların turizm sektörü içinde ahlaki statüden uzak birer meta olarak var oldukları çıkarımı yapılmıștır.

\section{ABSTRACT}

The matter of this study is to make critical analysis by introducing areas that animals are commodified in the tourism industry. The aim of the study is concordantly to make critique by opposing that animals ara commodified in the tourism industry and ethical responsibility of the tourism come up for discussion and bring forward proposals. This kind of study is not present in tourism literature in Turkey. Therefore, it is the first study about that in Turkey. In the study, there is a debate how about the moral responsibility of the supply and demand in tourism sector. Even if 23 animal-based tourism attractions which are reached all of them, data were collected from 17 managers of them via the semi-structured face-toface interviews. The visitors in these attractions were determined by way of convenience sampling and a total of 406 feedbacks were provided from participants and 388 of them were included in the analysis. The data obtained through face to face interviews were anzed by descriptive from participants and 388 of analysis and the data obtained by questionnaire were analyzed by descriptive statistics and structural equation model (SEM) and the results were evaluated. As a result of the analyzes, the demographical characteristics of the visitors who visited animal-based tourism attractions, the model of their given responses via SEM and the perceptions of the managers on commoditised animals were compared. Even thought visitors mostly express as an ecocentric, they said that their participated aims in animal-based tourism attractions are "an alternative to nature tourism", "educational tool", "family-oriented experience" and revealed antropocentric position. As to managers' answers of animal-based tourism businesses, these have come under (1) current situation, (2) ethical situation, (3) external environment and has commonly been concluded that the businesses are away from ethic responsibility towards animals. Both in terms of supply and demand, it has been deduced that the animals exist as a commodity far away from moral status within the tourism sector.

\section{GíRiş}

İnsan-doğa ilişkisi, insanın varoluşundan bugüne dek çeşitli değişim ve dönüşümler ile birlikte uzun bir süreci geride birakmıştır. Söz konusu bu süreç, antik çağda insanın doğanın bir parçası

\footnotetext{
${ }^{1}$ Bu makale, Sebahattin Emre DİLEK'in Dokuz Eylül Üniversitesi Sosyal Bilimler Enstitüsü Turizm İşletmeciliği ABD'de yazılan "Turizmin Hayvanlara Dair Ahlaki Sorumluluğunun Meta Eleştiri Bă̆lamında Değerlendirilmesi" başlıklı doktora tezinden derlenmiştir.
}

olduğu bilinci ile şekillenirken, Orta Çağ'da insanın ve doğanın birlikte Tanrı'nın yarattığı varlıklar olduğu inancına dönüşmüş ve doğal kaynakların kullanımını doğa lehine sınırlamıştır. Ancak, modern çağla birlikte doğanın canlılığı ve kutsallığı kavrayışı, yerini makine-doğa kavrayışına bırakmış ve insanın doğa ile ilişkisindeki kullanım hakkı genişletilmiştir. Endüstri devrimi ve kapitalizmin yükselişi ile birlikte, kendini 'doğanın efendisi' ilan eden insan, doğayla ilişki- 
sinde radikal bir dönüşüme uğramıştır. Artık söz konusu insan-doğa ilişkisi değil, insanın merkezde doğanın ise periferide yani arka planda yer aldığı, 'insan-çevre' ilişkisidir.

Bu ilişki aynı zamanda doğanın birer parças1 olan insanların ve insan olmayan hayvanlarm ilişkisini de kapsamakta ve bu yönüyle gerek türcülük gerekse yaşamın öznesi olma ve eşit gözetilme ilkesi gibi diğer etik tartışmaları gündeme taşımaktadır. Bu tartışmalar özellikle kapitalizmin yükselişine paralel olarak hayvanların metalaştırılması, farklı alanlarda farklı amaçlarla kullanılması noktasında hem etik kuramları hem de kapitalizmin bir eleştirisini gerekli kılmaktadır. Öyle ki Hall ve Brown da (2006:135) insanhayvan ilişkisi bağlamında yapılan etik tartışmaların, hayvanların insanların amaçlarına yönelik beş farklı kullanım alanı ile ilgili olduğunu ifade etmektedir. Bu beş farklı kullanım alanı: 1) Besin için hayvanların öldürülmesi, 2) Tıp deneylerinde hayvanların kullanılması, 3) Medikal olmayan ürün (kozmetik, deterjan vb.) testlerinde hayvanların kullanılması, 4) Kürkleri, dişleri veya derileri için hayvanların öldürülmesi, 5) Rekreatif faaliyetlerde (av turizmi, hayvan gösterileri vb.) hayvanların kullanılması şeklinde belirtilmektedir (Hall ve Brown 2006).

Söz konusu bu beş alan metalaştırılan hayvanların hem kapitalizmin eleştirel bir tahlili hem de etik kuramların hayvan etiği bağlamında ele alınması gerekliliğini ortaya koymaktadır. Bu doğrultuda çalışmanın amacı, kapitalizmin hükümranlığ1 altında olan turizm endüstrisinin hayvanları metalaştırma süreçleri, yöntemleri ve alanları ile ilgili olarak bir tespit yapmak ve bu tespit sonucunda etik kuramlar çerçevesinde meşru bir tartışma zemini ortaya koyabilmektir. Diğer bir ifade ile turizm endüstrisinde metalaştırılan hayvanların ahlaki bir statüye sahip olup olamayacaklarını tartışmak, turizm endüstrisini hayvan etiği bağlamında sorgulamak ve birtakım cevaplar üretebilmektir. Çalışmanın önemi de bu noktada ortaya çıkmaktadır. Öyle ki, bu tür bir çalışmanın Türkiye'de daha önce yapılmamış olması, ulusal alanyazındaki önemli bir boşluğun doldurulacağını göstermektedir.

Bu doğrultuda çalışmanın temel sorusu; "Turizm faaliyetine katılmanın ya da turizm faaliyet- leri içerisindeki zevk ve tercihlerin ahlaki yükü, hayvanların metalaştırılması karşısındaki ahlaki yüke ağır mı basıyor?" şeklindedir. Bu minvalde ortaya çıkan ve farklı düşünümleri gerekli kılan, bu yönüyle turizm endüstrisinin pek de hoşuna gitmeyecek türde bir değerlendirmeyi içermektedir. Nitekim turizm, dünyada bir milyardan fazla insanın katıldığı, bir trilyon dolardan fazla paranın harcandığı, ülke ekonomilerine ciddi katkilar sağlayan ve bunu yaparken de dokunduğu her şeyi metaya çevirmeyi başarabilen bir hizmet sektörüdür. Akademik çalışmalarda da ekonomik yönü ağır basan, pratiğin ve niceliğin önemli olduğu bir alandır. Ancak uluslararası alanda pek çok yazar, hayvan etiğinin turizm alanyazınında çalışılması ve önemsenmesi gereken bir konu olduğunu ifade etmektedir. (Cohen 2009; Fennell 2011; Markwell 2015).

\section{TURIZMDE INSAN-HAYVAN ETKILEŞIMINE YÖNELIK KAVRAMSAL ÇERÇEVE}

Hayvanlar, turizm endüstrisinin ve turistlerin ihtiyaçlarının/isteklerinin karşılanması amacıyla çok farklı alanlarda kullanılmaktadır (Fennell 2011: 2015). Bu alanlar; işçiler, göstericiler, yarışçllar, doğal yaşamı gözlemlenenler ve spor adı altında tüketime meta olanlar şeklinde sınıflandırılabilmektedir (Fennell 2011). Bu sinıflandırma doğrudan turizme katılanların hayvan odaklı turizm faaliyetlerini tüketim açısından ele almaktadır. Diğer yandan insan-hayvan ilişkisi bağlamında ilişkinin nasıl ve nerede oluştuğuna yönelik yapılan sınıflandırmalar da bulunmaktadır. Sınıflandırmalardan biri ilişkinin türü, ilişkide bulunulan ortam, hayvanların durumu ve ilişkinin aracıları başlıkları altında yapılmaktadır (Cohen 2009). Diğer bir sinıflandırmada ise otantik, yarı-otantik ve sahnelenen alanlar olmak üzere üç başlık altında bir sınıflandırmaya yer verilmektedir (Bulbeck 1999). Söz konusu sinıflandırmalar insan-hayvan ilişkisinin turizm endüstrisi içerisinde nasıl ortaya çıktığını göstermesi ve bu anlamda çalışmanın kuramsal çerçevesini belirleyebilmek adına önemlidir.

Yapılan sınıflandırmalar, insan-hayvan etkileşiminin biçimlerine göre değişiklik göstermektedir. Örneğin Bulbeck otantik, yarı-otantik ve 
sahnelenmiş alanlar olmak üzere üçlü bir sınıflandırmadan söz etmektedir (Bulbeck 1999). Yazarın otantik olarak adlandırdığ alanlar, turistlerin yaban hayatını yerinde gördükleri yerlerken; yarı-otantik şeklinde ifade edilen alanlar ise hayvanların belli bir alanda denetim altında oldukları doğal yaşam parkları ya da ulusal parklar gibi yerleri kapsamaktadır. Yazarın sahnelenmiş olarak sinıflandırdığı alanlar ise kafes ardında bekleyen, sınırlı bir alan içerisinde gösteri yapan ya da sahnelenen hayvanların bulunduğu yerlerdir. $\mathrm{Bu}$ yerler hayvanat bahçeleri, yunus parkları ve akvaryumlar gibi daha çok insanların eğlencelerine meta olan hayvanların yer aldığı alanlar şeklinde tanımlanabilmektedir.

Diğer bir sinıflandırma ise Beardsworth ve Bryman (2001) tarafından yapılmaktadır. Yazarlar sinıflandırmalarını yine insan-hayvan etkileşimi biçimine göre yapmakta ve hayvanların turizmde kullanımlarına göre dört ayrı sınıflandırmadan söz etmektedir. Bunlar; a) Rassal Yerler: İnsanların doğrudan, hayvanların kendi doğaları içerisinde sergiledikleri davranışları gözlemleyebildikleri yerler (balina gözlemciliği vb.) b) Sunulan Yerler: İnsanların, esaret altındaki hayvanları görebildikleri yerler (hayvanat bahçeleri, akvaryumlar vb.) c) Simgeler (Semboller): Edebi, sembolik ya da sanatsal olarak hayvanların temsili görüntüleri ya da resimleri (taş üzerine çizilen hayvan resimleri vb.) d) Sunulan Sahte İmgeler (Quasification ): Bu sınıflandırma hayvanların içlerinin doldurularak ürün şeklinde sunulduğu, içerisinde korku öğeleri de barındıran taxidermy (tahnit sanatı) şeklinde ifade edilmektedir.

Bir başka sınıflandırma Ballantyne vd. (2007) tarafından yapılmış ve diğerlerinden farklı olarak sinıflandırılan alanların olumlu ve olumsuz yönlerine de değinilmiştir. Bu sinıflandırmaya göre; birinci ve ikinci nesil sergiler, üçüncü nesil sergiler, hayvan şovları ve besleme programları, etkileşimli faaliyetler, yaban hayatı turizmi şeklinde beş alan belirlenmiştir (Ballantyne vd. 2007). Birinci, ikinci ve üçüncü nesil sergiler hayvanat bahçelerine karşılık gelmekte ve geçmişten günümüze hayvanat bahçelerinin doğal olmayan konumlarının giderek daha doğal hale getirildiğine işaret edilmektedir. Başka bir deyişle, hay- vanat bahçeleri birinci ve ikinci nesil sergiler içerisinde yer alırken, doğal yaşam parkları üçüncü nesil sergiler kapsamındadır. Hayvan şovları ve hayvan besleme programlarına ise hayvan sirkleri, yunus gösterileri ve köpekbalığ 1 besleme programları örnek gösterilebilir. Diğer yandan yunuslarla yüzme, yılan ile fotoğraf çektirme gibi bire bir hayvan ile insanın etkileşim içinde bulunduğu faaliyetler, etkileşimli faaliyetler başlığ 1 altında değerlendirilebilir. Yaban hayatı turizminde ise balina gözlemciliği, kuş gözlemciliği gibi hayvanların doğal yaşamının gözlemlenebildiği yerler kastedilmektedir. Ayrıca bu sınıflandırmada sınıflandırılan alanlara yönelik olarak olumlu ve olumsuz yönleri belirtmek adına, hayvan odaklı turizm faaliyetleri fayda ve maliyet şeklinde de iki yönden ele alınmıştır. Hayvan odaklı turizm faaliyetlerinin fayda ve maliyetleri içerisinde ele alınan ulaşılabilirlik, doğallık, duygusal etkileşim gibi olumlu etkiler (fayda) ile hayvan refahı ve doğal çevre üzerinde oluşabilecek olumsuz etkiler (maliyet) siralanmaktadır. İfade edilenler tartışmaya açık olmakla birlikte, insan odaklı, türcü ve biraz da misoterik bir bakış açısı yansıtması bakımından eleştirilebilir.

Diğer bir sınıflandırma da Cohen tarafından yapılmıştır. Cohen'in yapmış olduğu sınıflandırma diğerlerine göre daha bütünsel olması bakımından ayrışmaktadır. Bu sınıflandırmaya göre turizm sektöründe insan-hayvan ilişkisi, ilişkinin kurulduğu ortam (doğal, yarı doğal, yarı yapay, yapay), ilişkinin türü (etkileşimli, etkileşimsiz, ilişkisel), hayvanların durumu (vahşi, evcil, performansçılar, işçiler) ve aracılar (aracıll, aracısız) şeklinde bir çerçeve ortaya konulmaktadır (Cohen 2009).

Cohen'in insan-hayvan ilişkisine yönelik oluşturduğu kavramsal çerçeve, söz konusu ilişkinin nasıl bir ortamda gerçekleştiğini, ne tür bir ilişkinin ortaya çıktığını, hayvanların nasıl bir durumda bulunduğunu ve ilişkiye kimin ya da neyin aracılık ettiğini bütünsel bir açıdan ortaya koymaktadır. Örneğin balina gözlemciliği ele alınd1ğında, vahşi deniz canlılarının doğal ortamlarında etkileşimsiz bir şekilde insanlarla ilişki kurduğu söylenebilir. Balina gözlemciliğine yönelik bu tanımlama da, insan-hayvan ilişkisinin gerçek- 
leştiği ortam "doğal", kurulan ilişkinin türü "etkileşimsiz" ve hayvanların durumu da "vahşi" şeklinde ele alınmaktadır. Bu ilişkideki aracı ise -bunun bir tur organizasyonu kapsaminda olduğu bilindiğinde- "rehberler"dir.

Hall ve diğerleri ise Cohen'in ortaya koymuş olduğu kavramsal çerçeveden farklı olarak turizm sektörü içerisinde insan-hayvan ilişkisini yedi kategori altında ele almaktadır (Hall vd. 2003);

- Vahşi hayvanların keşfedilmesi (balina gözlemciliği, kuş gözlemciliği vb.),

- Karşıllıklı etkileşim için evcil hayvanlar (evde beslenen kediler, köpekler vb.),

- Gösteri için objeler (doğal yaşam parkları $\mathrm{vb}$.),

- Av için hedefler (balık avlama, sürek avı vb.),

- Eğitim kaynağı (Hayvanat bahçelerindeki bilgilendirmeler vb.),

- Efsanevi ya da sembolik sunumlar (Müzelerdeki figürler, el yapımı turistik ürünler vb.),

- Yardimci roller (turlarda katırların ya da eşeklerin kullanılması vb.)

Örnekleriyle birlikte sözü edilen tüm bu kategoriler, turizm sektörü içerisinde hayvanların pek çok farklı alanda metalaştırıldığını göstermesi bakımından önemlidir. Uluslararası yazında turizm sektörünün hayvanlar üzerinden nasıl ekonomik bir fayda elde ettiğine yönelik çalışmalar da bulunmaktadır. Örneğin Cloke ve Perkins (2005) Yeni Zelenda'nın Kaikoura kasabasını her yıl ortalama 1,5 milyon kişinin ziyaret ettiğini ve bunun yalnızca balinalar ile yunuslar sayesinde gerçekleştiğini ifade etmektedir. Yazarlar yaptıkları çalışmada, turistlerin balina gözlemciliğini "özel, sihirli ve unutulmaz bir deneyim" şeklinde ifade ettiklerini, yunuslarla yüzmeyi ise "nefes kesici, mutluluk verici" bir deneyim olarak adlandırdıklarını söylemektedir (Cloke ve Perkins 2005). Söz konusu örnekte de olduğu gibi hayvanlar turizm sektörü için önemli bir kaynak olarak görülmekte ve hayvanların turizm sektöründe kullanım alanları; esaret altındakiler, turizm faaliyetlerine hizmet edenler/fiziki ve duygusal işçiler, yarışmacılar/rekabete maruz bırakı- lanlar, spor uğruna katledilenler ve doğal yaşamı gözlemlenenler şeklinde beş temel kategoriden oluşmaktadır (Fennell 2011).

\section{HAYVAN ETIĞi TARTIŞMALARI}

Besin, tıp deneyleri, kozmetik ürün deneyleri, kürk/diş/deri ticareti ya da rekreasyonel faaliyetler olsun geçmişten günümüze hayvanların fark1 alanlarda kullanımı, etik tartışmaları da beraberinde getirmiştir. Çalışmanın amacına uygun olarak bu kısımda bahsedilen etik tartışmalar ise hayvanların turizm faaliyetleri de dâhil olmak üzere rekreatif faaliyetler kapsamında metalaştırılması üzerinde yürütülmektedir. Ziyaretçihayvan ilişkisinin turizm faaliyetleri içerisinde hangi alanlarda ortaya çıktığ1 ve nasıl oluştuğu bir önceki kısımda ortaya konularak, etik tartışmanın minvali de bu yönde olacaktır. Geçmişten günümüze süregelen hayvan etiği tartışmaları günümüzde Singer (2002), Regan (2007) ve Francione'nin (2008) felsefi temelde yapmış oldukları tartışmalar ile devam etmektedir. Dolayısıyla turizmin hayvanlara yönelik ahlaki sorumluluğunun tartışılabilmesi adına, söz konusu teorisyenlerin tartışmalarının ve bu tartışmalara ilişkin temel argümanların bilinmesi gerektirmektedir.

Singer'ın görüşlerini temellendirdiği faydacı etiğin 18. yüzyıldaki öncüsü Jeremy Bentham, hangi varlıkların ahlaki statüye sahip olacağı konusunda; o varlığın rasyonel bir varlık olup olmaması değil, acı çekme yetisine sahip olup olmamasının önemini belirtmektedir. Bentham, sadece insanların ahlaki değere sahip olduğu ya da olması gerektiği yönündeki geleneksel düşünceyi sorgulayarak, pek çok hayvanın hazzı ve acıyı deneyimleyebildiklerini, bundan dolayı insanların yapmış oldukları eylemlerde, hayvanların çıkarlarını da ahlaki bir zorunluluk olarak göz önünde bulundurmaları gerektiğini belirtmektedir. Peter Singer da bu anlamda Bentham'ın görüşleri ile paralel bir faydacı düşünür olarak, faydacılara göre en fazla sayıda varlık için en fazla faydanın, hazzın ya da mutluluğun sağlanmasının ahlaki açıdan önemli olan tek mesele olduğunu ifade etmektedir.

Peter Singer'ın Bentham'dan farklılığ 1 ise Bentham'ın görüşlerini daha net bir hale getire- 
rek bu görüşleri derinleştirmesidir. Singer, faydacıların savunduğu "insan olmayan hayvanların geleceğe dair herhangi bir planlama yapamamaları ve bu nedenle ölerek temelde bir şey kaybetmedikleri" yönündeki görüşe katılarak, hayvanların acı çekmeme konusunda çıkarlarının olduğunu, ancak varlıklarını sürdürmek gibi bir çıkarlarının olmadığını ifade etmektedir. Bu nedenden ötürü Singer, endüstriyel hayvancılığa belli ölçüde karşı çıksa da hayvanların yenmemesi konusunda bir ahlaki gerekliliğin olmadığını düşünmektedir. Öyle ki, kitabında da sağlıklı koşullarda yetiştirilmiş ve acı çektirilmeden öldürülmüş bir hayvanı yiyen insana, ahlaki açıdan saygı duyulabileceğini belirtmektedir. Özetle Singer, "Hayvan Özgürleşmesi" kitabıyla hayvanların da etik bir tartışmanın parçası olduklarını, insanlar kadar hayvanların da acı çekmeme hakkına sahip olduklarını savunmakla birlikte, doğal bir hiyerarşik yapının da bulunduğunu vurgulamaktadır. Bu görüş, insanları birer birey olarak kabul ederken, hayvanları insan amaçları için kullanılan ve yerleri doldurulabilir birer metadan öteye geçirmemektedir. Bu da Singer'ın bir anlamda antroposentrik ve türcü bir faydacı etik savunucusu şeklinde yorumlanmasına vesile olmaktadır.

Tom Regan, Singer'dan farklı olarak belirli bilişsel ve deneyimsel kapasitelere sahip her varlığın içkin ahlaki değere sahip olduğunu öne süren deontolojik (Kant etiği/ödev etiği) ve mutlakçı bir yaklaşıma sahiptir. Singer'ın Benthamcı bakış açısının aksine, Regan Kantçı bir açıdan konuyu ele almaktadır. Dolayısıyla iki farklı teorinin savunucuları arasında bir rekabetten de söz edilebilir. Regan, içkin ahlaki değerin acı ve haz duyma yetisi ile ilgili olmadığını, mutlak ve çiğnenemez bir değer olduğunu ifade eden Kant ve Kant etiğinden yola çıkmaktadır. Kant'ın mutlakçı ve deontolojik (ödev etiği) yaklaşımında kullandığ 1 temel terimleri ve yaptığı eleştirileri takip eden Regan, Kant'in sadece rasyonel varlıkların içkin ahlaki değere sahip oldukları yönündeki görüşünü sorgulayarak yeniden değerlendirmektedir. Kant'a göre, belirli varlıklar doğalarında bulunan mükemmeliyetten ötürü mutlak ahlaki saygıyı hak etmektedirler ve doğa- ları gereği bu mutlak ahlaki saygıyı hak etmesi gereken yalnızca insandır. Regan'a göre Kant'ın bu türcü ve antroposentrik savunusundaki hata, mutlak ahlaki değere ve statüye sahip olmak için rasyonel olmanın temel gereklilik olduğunu düşünmesidir.

Regan, ahlaki kaygının, ahlaki eylemi gerçekleştiren kadar o eylemden etkilenenleri de kapsadığını düşünmektedir. Buradan hareketle, Regan'ın savunduğu etik görüş rasyonel olmaktan çok bir yaşamın öznesi olma kapasitesi üzerinde şekillenmektedir. Regan, kendi yaşamı kendisi için bir anlam ifade eden her varlığın -ki bu anlam dilsel bir rasyonaliteye sahip olan insanlarınki ile aynı olmasa da- yaşamın öznesi olduğunu ve dolayısıyla içkin ahlaki değere sahip olduğunu savunmaktadır.

Bir diğer teorisyen Gary Francione hem Singer hem de Regan'ın görüşlerinden yararlanmakta, fakat ahlaki ve ontolojik hiyerarşiye tümden karşı olan bir duruşu savunmaktadır. Francione de Singer gibi haz ve acıyı deneyimleme yetisinin ahlaki statü için uygun bir ölçüt olduğunu savunur. Bununla birlikte, Regan'ın ahlaki değerin tüm varlıklar için içkin olduğu görüşüne de katılmaktadır.

Ancak Singer ve Regan'dan farklı olarak Francione, bir varlığın sahip olduğu bilişsel yetinin ahlaki statüyle ilgili değerlendirmelerde tamamıyla ilişkisiz olduğunu öne sürmektedir. Başka bir ifadeyle, eğer varlık hissedebilir bir varlık ise diğer tüm hissedebilir varlıklar ile eşit olarak içkin ahlaki değere sahiptir. Francione, varlıkların yaşamın öznesi olmasının ahlaki değere sahip olmak için yeterli olduğunu ancak gerekli olmadığını öne süren Regan'ın aksine, hissetme yetisinin doğrudan ahlaki statüye sahip olmak için hem yeterli hem de gerekli olduğunu öne sürmektedir. Francione buradan hareketle, rasyonel olarak daha gelişmiş olan bir insan ile daha az gelişmiş bir hayvanın çıkarlarını eşit düzeyde görmektedir. Örneğin bir köpeğin, bir kedinin ya da bir filin çıkarları, bir insanın çıkarları ile eşit şekillerde göz önünde bulundurulmalıdır. Ancak bu durum bir köpeğe, kediye ya da file, bir insana davranıldığı gibi davranılmasını da gerektirmemektedir. Nitekim bir hayvanın çıkarlarının, 
bir insanın çıkarları ile eşit olarak gözetilmesi o hayvanın oy hakkının bulunduğu anlamına gelmemektedir. Burada Francione'nin kastettiği eşit gözetilme durumu, bir hayvanın acı çekmemekteki çıkarının bir insanın acı çekmemekteki çıkarı ile eşit değerlendirilmesi gerekliliğidir. Buna ek olarak Francione, Singer ve Regan'ın hayvanların varlığını sürdürmekte çıkarlarının olmadığı yönündeki görüşlerini de eleştirerek, insan ve hayvan arasında nasıl acı çekme konusunda ortak bir çıkar söz konusu ise eşit gözetilme ilkesinden yola çıkarak varlıklarını sürdürme konusunda da ortak çıkarlara sahip olduklarını söylemektedir.

Singer, Regan ve Francione'nin görüşleri belli noktalarda ayrilsa da hayvanların mevcut ahlaki durumlarının iyileştirilmesi konusunda hemfikirdirler. Dolayısıyla bu üç teorisyenin görüşleri çerçevesinde yapılacak çıkarım, hayvanların hemen her sektörde metalaştırılmasıdır. Çünkü bir metanın, yalnızca kullanım ve değişim değeri ya- ni ekonomik değeri bulunmaktadır. Bu çıkarım, çözümünün yalnızca etik tartışmalar ile değil, meta eleştirisi çerçevesinde de bir etik tartı̧̧ma ile mümkün olabileceğini göstermektedir. Bu noktada, turizmin hayvanlar üzerinden yaratmış olduğu meta üretim alanlarının, insan-hayvan etkileşimi bağlamında değerlendirilmeli ve söz konusu alanların etik tartışmalar için ne anlam ifade ettiği bilinmelidir. Tablo 1, turizmin hayvanlar üzerinden gerçekleştirdiği meta üretim alanlarını ve bu alanların etik tartışma konularını göstermektedir.

Tabloda yer alan meta üretim alanları kısmı, aynı zamanda turizm aktiviteleri şeklinde de ifade edilebilir. Diğer yandan "faydalar" başlı̆̆ 1 altında belirtilen ifadeler ise turizmin hayvanların metalaştırılması konusundaki antroposentrik savunuları şeklinde de değerlendirilebilir. Tablodan da anlaşılacağı gibi hayvan etiği teorileri içerisinde az önce sözü edilen içkin ahlaki değer, acı

Tablo 1. Hayvan Odaklı Turizm Faaliyetlerinde Etik Konular

\begin{tabular}{|c|c|c|}
\hline Meta Uretim Alanları & Etik Tartışmalar & Faydalar? \\
\hline $\begin{array}{l}\text { Doğal ortamında yaban haya- } \\
\text { t1 gözlemciliği }\end{array}$ & $\begin{array}{l}\text { Hayvanların çeşitliliŭi, hayvan türleri } \\
\text { ve ekosistem üzerindeki etkiler }\end{array}$ & $\begin{array}{l}\text { Turistin mutluluğu, ekosistemin, } \\
\text { hayvan türlerinin korunmasına } \\
\text { yönelik edinilen bilgi }\end{array}$ \\
\hline $\begin{array}{l}\text { Doğal ortamlarında hayvan- } \\
\text { ların beslenmesi }\end{array}$ & $\begin{array}{l}\text { Hayvanların alışkanlık kazanmašl, } \\
\text { hayvanlarda davranışsal değişiklikler, } \\
\text { hayvanların sağlık durumlarına ilişkin } \\
\text { etkiler }\end{array}$ & $\begin{array}{l}\text { Turistin mutluluğu, daha yoğun bir } \\
\text { insan-hayvan etkileşimi, koruma } \\
\text { bilinci ve ekosistem üzerindeki } \\
\text { faydalar }\end{array}$ \\
\hline $\begin{array}{l}\text { Esaret altındaki hayvanların } \\
\text { gözlemlenmesi ve beslenmesi }\end{array}$ & $\begin{array}{l}\text { Hayvan hakları, meta üretim zinciri } \\
\text { içerisindeki hayvanlar, hayvanların } \\
\text { çlkarlarını göz ardı etmek }\end{array}$ & $\begin{array}{l}\text { Nesli tükenme tehlikesi altındaki } \\
\text { hayvanlara yönelik koruma prog- } \\
\text { ramları, gözlemcilerin mutluluğu, } \\
\text { eğitim, koruma programı için kay- } \\
\text { nak yaratmak }\end{array}$ \\
\hline $\begin{array}{l}\text { Esaret altında tutulan hay- } \\
\text { vanların gösterileri }\end{array}$ & $\begin{array}{l}\text { Hayvanları eğitmenin zararları ya da } \\
\text { onlara verdiği acı, hayvanların çıkarla- } \\
\text { rını göz ardı etmek }\end{array}$ & $\begin{array}{l}\text { Hayvan koruma programları için } \\
\text { gelir elde etmek, yaban hayatını } \\
\text { korumak için destek olmak }\end{array}$ \\
\hline Avcllik & $\begin{array}{l}\text { Hayvanların öldürülmesi, hayvan hak- } \\
\text { ları ihlalleri }\end{array}$ & $\begin{array}{l}\text { Avcinın mutluluğu, hayvan-avci } \\
\text { arasındaki deneyimsel ilişkinin } \\
\text { kuvvetlenmesi, av ürünleri }\end{array}$ \\
\hline $\begin{array}{l}\text { Yeşil Avcılık (Yakalama ve } \\
\text { serbest birakma) }\end{array}$ & $\begin{array}{l}\text { Hayvanların acı çekmeleri ve stres } \\
\text { altında kalmaları }\end{array}$ & $\begin{array}{l}\text { Hayvan-avcı arasındaki deneyim- } \\
\text { sel ilişkinin kuvvetlenmesi, doğal } \\
\text { hayatı koruma }\end{array}$ \\
\hline $\begin{array}{l}\text { Turist menülerinde yer alan } \\
\text { yaban hayvanlarının yenmesi }\end{array}$ & $\begin{array}{l}\text { Hayvanların öldürülmesi, hayvanlara } \\
\text { acı çektirilmesi, stres altında tutulma- } \\
\text { ları, hayvanların gereğinden fazla yok } \\
\text { edilmesinin hayvan türleri ve ekosis- } \\
\text { tem üzerindeki olumsuz etkileri }\end{array}$ & $\begin{array}{l}\text { Turistin mutluluğu, yerel halkın } \\
\text { gelir elde etmesi }\end{array}$ \\
\hline $\begin{array}{l}\text { Hayvanlar kullanılarak ger- } \\
\text { çekleştirilen turlar }\end{array}$ & $\begin{array}{l}\text { Hayvanların acı ve istırap çekmeleri, } \\
\text { hayvan çıkarlarının gözetilmemesi, } \\
\text { hayvan hakları ihlalleri }\end{array}$ & $\begin{array}{l}\text { Turistin mutluluğu, turist-hayvan } \\
\text { etkileşiminin artması }\end{array}$ \\
\hline $\begin{array}{l}\text { Yarışmaya maruz bırakılan } \\
\text { hayvanlar }\end{array}$ & $\begin{array}{l}\text { Hayvanların acı çekmeleri, hayvanla- } \\
\text { rın öldürülmesi, sakat bırakılmaları, } \\
\text { hayvan hakları ihlalleri }\end{array}$ & Turistin mutluluğu ve eğlenmesi \\
\hline
\end{tabular}


çekmeme çıkarı, eşit gözetilme ilkesi ya da yaşamin öznesi olma gibi hayvanlara dair kullanılan ve savunulan pek çok kavram, turizmin hayvanlar üzerinden yaratmış olduğu aktivitelerde geçerli olmamaktadır. Öyle ki, turizmin savunmuş olduğu faydalar, "turist merkezli" ya da başka bir deyişle insanı merkeze alan, hayvanları ötekileştiren antroposentrik ve türcü bir yaklaşımın savunularıdır. Dolayısıyla ekonomik düzlemdeki pragmatik görüşün hakim olduğu turizm, zaten metalaştırdığı hayvanların içkin ahlaki değere sahip olup olmaması yönündeki tartışmaların çok uzağında kalmaktadır.

\section{YÖNTEM}

Araştırmada, nitel ve nicel araştırma tasarımının her ikisi de kullanılmıştır. Çalışma, turizm sektöründe hayvanların metalaştırılmasının eleştirisi üzerinden şekillendiği için mevcut duruma ilişkin hem arz hem de talep boyutu dikkate alınmıştır. Bu doğrultuda, hayvan odaklı turizm çekiciliklerine sahip işletmelerin yöneticileri ile yarı yapılandırılmış görüşme formu aracılığıyla derinlemesine mülakatlar gerçekleştirilirken, diğer yandan söz konusu işletmelere gelen ziyaretçilerden de anket formu aracılığıyla veriler toplanmıştır. Araştırma verileri 2015-2016 yaz aylarında olmak üzere toplam altı aylık süreçte elde edilmiştir.

Araştırmanın nitel kısmında, Türkiye'de aktif durumda olan toplam 23 hayvan odaklı turizm işletmesinin yöneticisi ile görüşme yapılmak istenmiş, ancak 17 yönetici ile görüşme gerçekleştirilebilmiştir. Bunun yanı sıra toplamda 20 işletme gezilmiştir. Nicel kısımda ise Gaziantep, Antalya (Merkez, Alanya ve Kemer), İzmir, Bodrum, Marmaris, Ankara, Eskişehir, İstanbul, Kocaeli illerinde hayvanat bahçesi (3), yunus gösteri merkezi (7), hayvan temalı park (2), wildpark (2), akvaryum (5), doğal yaşam parkı (1) olmak üzere toplam 20 işletmeye gelen ziyaretçilerden toplam 406 veri toplanmıştır. Bunların 18 tanesi ön kabul şartlarına uymadığ için elenerek toplam 388 veri değerlendirmeye alınmıştır. Ana kütlenin bilinememesi ve araştırmanın keşifsel olması nedeniyle örneklem sayısında 384'ü geçmek, analizlerin sağlıklı sonuçlar verebilmesi açısından önemli görülmüştür. Nitekim yazarlar örneklem büyüklügünün 384 olmasının analizler ve sonuçlar için önemli olduğunu dile getirmektedir (Krejcie ve Morgan 1970; Sekaran ve Bougie 2016).

Çalışmada kullanılan hem yarı yapılandırılmış görüşme formu (toplam 10 soru) hem de kullanılan ölçek Amir Shani'nin (2009) “Tourists' Attitudes Toward The Use Of Animals In Tourist Attractions: An Empirical Investigation" adlı doktora tezinde kullandığ ${ }_{1}$ ölçek ile Thompson ve Barton' in (1994) “Ecocentric and Anthropocentric Attitudes Toward The Environment" ad11 çalışmasında ilk defa kullanılan ölçek dikkate alınarak oluşturulmuştur. Ölçekte, ziyaretçilerin hayvanlara ve hayvan odaklı turizm çekiciliklerine yönelik algısı, hayvan odaklı turizm çekiciliklerine ilişkin kabul etme düzeyleri ve hayvan odaklı turizm çekiciliklerine ilişkin muhtemel ziyaretleri olmak üzere dört temel boyut bulunmaktadır. Söz konusu boyutlar ise toplam 12 alt boyuttan meydana gelmektedir. Elde edilen veriler, frekans ve yapısal eşitlik modeli ile analiz edilerek sonuçlar değerlendirilmiştir. Faktör ve regresyon analizinin bir kombinasyonunu içerisinde barındırdığı için (Kline 2015), YEM'in bu araştırma için uygun olacağı düşünülmüştür. Araştırmanın ana kütlesini Türkiye'de bulunan hayvan odaklı çekicilikleri ziyaret edenler oluşturmaktadır. Ancak, tüm ziyaretçilere ulaşılmaSı mümkün olmadığından örnekleme yapılmış ve örnekleme yöntemi olarak kolayda örnekleme metodu tercih edilmiştir.

Çalışmanın nitel ayağında yer alan yarı yapılandırılmış görüşme formunda ise işletmeyi tanımaya yönelik sorular, o işletme ile hayvanlar arasındaki ilişkiye dair sorular, o işletmeye gelen ziyaretçiler ile hayvanlar arasındaki ilişkiye yönelik sorular ile toplumsal farkındalık, hayvan hakları örgütleri ile olan ilişkiler, denetim ve halkla ilişkiler faaliyetlerine yönelik sorular yer almaktadır. Söz konusu sorulardan elde edilen veriler ise araştırma sorularının ortaya koyduğu temalara göre düzenlenmiş ve betimsel analiz yoluyla değerlendirilmiştir.

Çalışmada her iki yöntemin de kullanılmasının nedeni, arz ve talep boyutunda bir karşılaştırma yaparak, hayvanlar üzerinden gerçekleştirilen 
metalaştırma süreçlerine ilişkin daha sağlıklı bir bilimsel bilgi ortaya koymayı amaçlamaktır. Böylelikle hem arzı sunanlar hem de talebi oluşturanlar açısından hayvanların turizm sektöründe meta olarak kullanılmasının karşılaştırmalı bir eleştirisi yapılabilmiştir.

\section{Araştırmanın Temel Sorunsalı ve Hipotezlerin Oluşturulması}

Araştırmanın temel sorunsalı ya da sorusu "Hayvan odaklı turizm faaliyetine katılmanın ya da bu faaliyetler içerisindeki zevk ve tercihlerin ahlaki yükü, hayvanların metalaştııılması karşısındaki ahlaki yüke ağır mı basıyor?" şeklinde bir felsefi düşünümden hareketle turizmin hayvanlara yönelik ahlaki sorumluluğunu arz ve talep boyutu ile irdelemektir. Bu bağlamda, araştırmanın talep boyutunda (nicel) dört hipotez ortaya konulmuş ve YEM modelindeki sonuçlara göre sınanmıştır. Söz konusu hipotezler;

Hı: Ziyaretçilerin hayvanların çıkarlarına yönelik algisı artarken, hayvan odaklı turizm çekiciliklerine yönelik algısı azalmaktadır.

$\mathrm{H}_{2}$ : Ziyaretçilerin hayvan odaklı turizm çekiciliklerine yönelik algıları artarken, esaret altında olan hayvanların bulunduğu turizm çekiciliklerini kabul edilebilir bulmaktadırlar.

$\mathrm{H}_{3}$ : Ziyaretçilerin hayvan odaklı turizm çekiciliklerine yönelik algıları artarken, performans sergileyen hayvanların bulunduğu turizm çekiciliklerini kabul edilebilir bulmaktadırlar.

$\mathrm{H}_{4}$ : Ziyaretçilerin hayvanların bulundukları ortama yönelik algısı artarken, hayvan odaklı turizm çekiciliklerine yönelik algısı azalmaktadir.

Oluşturulan dört hipotez bütünsel olarak, yukarida ifade edilen sorunun talep boyutunda cevabını ortaya koymayı amaçlamaktadır. Böylelikle arz boyutunda (nitel) hayvan odaklı turizm işletmeleri yöneticilerinin vermiş oldukları cevaplar ile talep boyutunda (nicel) ortaya çıkan cevaplar, turizmin genel olarak hayvanlara yönelik ahlaki sorumluluğunun düzeyini göstermiş olacaktır.

\section{ANALIZ VE BULGULARIN YORUMLANMASI}

Hayvan odaklı turizm işletmeleri yöneticileri ile yapılan görüşmelerden elde edilen veriler arz boyutu altında; söz konusu bu işletmelere gelen ziyaretçilere uygulanan anketlerden elde edilen veriler ise talep boyutu altında değerlendirilmiştir.

\section{Arz Boyutu}

Araştırmanın nitel yani bir başka ifadeyle arz boyutunu hayvan odaklı turizm işletmeleri yöneticileri ile yarı yapılandırılmış görüşme formu aracılığıyla gerçekleştirilen derinlemesine görüşmeler oluşturmaktadır. Bu görüşmeler neticesinde elde edilen veriler betimsel analiz yoluyla dört aşamada ortaya konulmuştur.

- Görüşme yoluyla elde edilen veriler (1) mevcut durum, (2) etik durum, (3) dış çevre altında düzenlenmiştir.

- Elde edilen veriler okunmuş, düzenlenmiş ve mantıklı bir biçimde bir araya getirilmiştir. Daha sonra söz konusu temalara ilişkin veriler işlenerek, sonuç kısmında frekans tablosu şeklinde yer verilen doğrudan alıntılar seçilmiştir.

- Üçüncü aşamada, veriler daha kolay anlaş1labilir bir dille tanımlanmıştır.

- En son aşamada ise elde edilen bulgular yorumlanarak, neden-sonuç ilişkileri temelinde hem etik kuramlar açısından hem de meta üretiminin eleştirel tahlili ile değerlendirilmiştir.

Söz konusu aşamalardan sonra ortaya çıkan üç ana tema altında 10 alt tema bulunmaktadır. Bunlar; 1) mevcut durum (işletme türü, işletmenin kuruluş tarihi, uluslararası üyelik, ortalama ziyaretçi sayısı); (2) etik durum (işletme-hayvan, işletme-ziyaretçi, ziyaretçi-hayvan ilişkisi) (3) diş çevre (işletme-toplum, işletme-STK, işletme-devlet ilişkisi) şeklindedir. Görüşme yapılan işletme yöneticilerinin verdiği bilgiler doğrultusunda "mevcut durum" teması altında ortaya çıkan durum Tablo 2'de ayrıntılı olarak verilmektedir.

Bu bilgiler ışığında etik durum ve dış çevre olarak adlandırılan diğer iki kategori altında hayvan odaklı turizm faaliyetlerinin aktörleri konu- 
S. Emre Dilek ve Ebru Günlü-Küçükaltan

Tablo 2. Görüşme Yapılan Hayvan Odakl Turizm İşletmelerinin Mevcut Durumu

\begin{tabular}{|c|c|c|c|c|c|}
\hline İşletmeler & $\begin{array}{c}\text { Kuruluş } \\
\text { Tarihi }\end{array}$ & $\begin{array}{c}\text { İşletme } \\
\text { Tipi }\end{array}$ & Üyelik & Ort. Ziyaretçi Sayısı & Hayvan Sayısı \\
\hline Dolphinarium 1 & 2008 & Özel & - & Yıllık 1 Milyon kişi & $\begin{array}{l}1 \text { Mors, } 1 \text { Fok, } 2 \text { Yunus ve } 1 \\
\text { Beyaz Balina }\end{array}$ \\
\hline Dolphinarium 2 & 2010 & Özel & - & $\begin{array}{l}\text { Yaz Sezonu boyunca } \\
\text { 35- } 40 \text { bin kişi }\end{array}$ & 4 Yunus, $\begin{array}{l}1 \text { Fok, } 1 \text { Deniz } \\
\text { Aslanı }\end{array}$ \\
\hline Dolphinarium 3 & 2006 & Özel & - & Yıllık 200 bin kişi & $\begin{array}{c}4 \text { Yunus, } 2 \text { Beyaz Balina, } 1 \\
\text { Mors }\end{array}$ \\
\hline Dolphinarium 4 & $\begin{array}{l}2013 \text { (tek- } \\
\text { rar açlldı) }\end{array}$ & Özel & - & - & 3 Yunus \\
\hline Dolphinarium 5 & 2007 & Özel & - & - & 5 Yunus \\
\hline Hayvanat Bahçesi 1 & 2001 & Kamu & - & $\begin{array}{l}\text { Yillık 2.5 Milyon } \\
\text { kişi }\end{array}$ & 264 türde 6814 hayvan \\
\hline Hayvanat Bahçesi 2 & 1990 & Kamu & - & Y1llık 350 bin kişi & 200'ün üzerinde hayvan \\
\hline Hayvanat Bahçesi 3 & 1993 & Özel & EAZA & Y1llık 750 bin kişi & $\begin{array}{l}286 \text { türde 3600'den fazla hay- } \\
\text { van }\end{array}$ \\
\hline Doğal Yaşam Parkı & 2008 & Kamu & EAZA & Yıllık 1 Milyon kişi & $\begin{array}{c}130 \text { türde } 1500 \text { 'den fazla hay- } \\
\text { van }\end{array}$ \\
\hline $\begin{array}{l}\text { Akvaryum } 1+ \\
\text { Vahşi Yaşam Parkı }\end{array}$ & 2012 & Özel & - & Yıllık 1 milyon Kişi & $\begin{array}{c}\text { Toplam } 40 \text { binin üzerinde } \\
\text { kara ve deniz canlısı }\end{array}$ \\
\hline Akvaryum 2 & 2012 & Özel & - & Yıllık 500 bin kişi & 12 bin deniz canlısı \\
\hline Akvaryum 3 & 2009 & Özel & WAZA & Y1llık 600 bin kişi & 15 bin deniz canlısı \\
\hline $\begin{array}{l}\text { Akvaryum } 4+ \\
\text { Vahşi Yaşam Parkı }\end{array}$ & 2011 & Özel & WAZA & Yıllık 2 milyon kişi & $\begin{array}{c}\text { Toplam } 15 \text { bin kara ve deniz } \\
\text { canlisı }\end{array}$ \\
\hline Akvaryum 5 & 2014 & Özel & - & $\begin{array}{l}1,5 \text { y1l içerisinde } \\
\text { toplam } 1 \text { milyon kişi }\end{array}$ & 2150 deniz canlısı \\
\hline Vahşi Yaşam Parkı & 2015 & Özel & - & $\begin{array}{l}\text { Hedef yıllık } 1 \text { mil- } \\
\text { yon kişi }\end{array}$ & $\begin{array}{c}100 \text { farklı türde } 150 \text { 'den fazla } \\
\text { hayvan }\end{array}$ \\
\hline $\begin{array}{l}\text { Hayvan Temalı } \\
\text { Park } 1\end{array}$ & 2011 & Özel & - & Yillık 300 bin kişi & $\begin{array}{l}\text { Canlı hayvan bulunmamak- } \\
\text { tadır. Bire bir boyutlarda } \\
\text { dinazor simülasyonları var- } \\
\text { dir. }\end{array}$ \\
\hline $\begin{array}{l}\text { Hayvan Temalı } \\
\text { Park } 2\end{array}$ & 2012 & Özel & - & Y1llık 100 bin kişi & $\begin{array}{l}\text { Bire bir boyutlarda dinazor } \\
\text { simülasyonları vardır. }\end{array}$ \\
\hline
\end{tabular}

munda olanların birbirleriyle olan ilişkileri ve bu ilişki ağının hayvanların metalaştırılması açısından nasıl bir rol oynadığı irdelenmiştir. İşletme hayvan ilişkisi, işletme - ziyaretçi ilişkisi, ziyaretçi - hayvan ilişsisi etik durumu açılamak üzere belirlenen kategoriler, işletme - toplum, işletme - STK ve işletme - devlet ilişkisi ise dış çevreyi açiklamak üzere belirlenen kategoriler olmuştur. Bu kategoriler işletme bakış açısıyla hayvanların ahlaki ve hukuki değerini ortaya koymaktadır. Görüşmelerden elde edilen bulgular içerisindeki en dikkat çekici nokta o işletmenin birer öznesi konumunda olan hayvanların gerek işletme politikalarında gerekse devlet politikalarında tam anlamıyla ahlaki bir statüye sahip olmamalarıdır. Her ne kadar belli ölçüde bir toplumsal farkın- dalık var olsa da bu iki mekanizmayı hayvanlara dair ahlaki ve yasal sorumluluktan uzaklaştıran üçüncü önemli unsur ise söz konusu işletmelere giden ziyaretçilerdir. Başka bir deyişle talebi yaratanlardır.

\section{Talep Boyutu}

Araştırma kapsamında ulaşılan 388 katılımcıdan $210^{\prime}$ u erkek $(\% 54,1), 178^{\prime} \mathrm{i}$ ise kadındır $(\% 45,9)$. Katılımcıların \%77,6'sı, başka bir deyişle 301 kişi evli olduğunu, 87 kişi ise bekâr olduğunu belirtmiştir. Bunun yanı sıra, 18 yaşından küçük tek çocuğu olanların oranı \%34,3 (133 kişi), birden fazla çocuğu olanların oranı ise \%39,2'dir (152 kişi). Bu bağlamda, hayvan odaklı turizm çekiciliklerini ziyaret edenlerin profili daha çok 
evli ve çocuklu ailelerdir. Hayvan odaklı turizm faaliyetlerini daha çok talep eden ziyaretçilerin profili genel hatlarıyla; evli, 18 yaşından küçük bir ya da birden fazla çocuğu olan, daha çok özel sektörde çalışan, eğitim ve gelir seviyesi yüksek, 25 - 45 yaş aralığında kişilerdir. Bu durum, hayvan odaklı çekiciliklerin çocuklar için bir eğitim aracı olarak algılandığını, aileler için çocuklarıyla bir şeyler paylaşabildiği bir boş zaman etkinliği olduğunu göstermektedir. Başka bir ifadeyle hayvan odaklı turizm faaliyetleri çoğunlukla aile odaklı bir deneyimi yansıtmaktadır. Hayvan odaklı turizm işletmelerini ziyaret edenlerden elde edilen veriler neticesinde, ortaya çıkan durum ise Yapısal Eşitlik Modellemesi (YEM) üzerinden açıklanmaya çalışılmıştır. Söz konusu model Şekil 1'de verilmektedir.

Görüldügü üzere, ziyaretçilerin hayvanlara yönelik algılamalarının nedensel boyut olarak düşünüldügü iki boyut (hayvan çıkarı, hayvan ortamı) tek tek ele alınarak, hayvan odaklı turizm çekiciliği ölçeğinde yer alan altı boyut (koruma, aile odaklı deneyim, doğa turizmine alternatif, bilimsel araştırma, eğlence ve eğitim) ile ilişkilendirilmiştir. Bununla birlikte modele, ziyaretçilerin hayvan odaklı turizm çekiciliklerini kabul etme düzeyleri ve bu çekiciliklere ilişkin muhtemel ziyaret niyetleri de dâhil edilmiştir. Şekil 1'de de görüldüğü gibi toplam 12 boyutta turizm sektöründe turist/ziyaretçi - metalaştırılan hayvanlar ilişkisi ortaya konulmaya çalışılmıştır. Bu doğrultuda başlangıçta oluşturulan hipotezler (toplam dört hipotez) ile sonuçlar karşılaştırılmıştır.

Söz konusu hipotezlerin irdelendiği araştırmada, modele yönelik elde edilen uyum ölçütleri ise; $\chi^{2}=142,26 \mathrm{df} .=39 ; \chi^{2} / \mathrm{df}=3,64$, RMSEA $=0,080$, NFI $=0,96$, NNFI $=0,96$, CFI $=0,97$, IFI $=0,97$, $\mathrm{RFI}=0,94, \mathrm{GFI}=0,94, \mathrm{RMR}=0,048^{\prime}$ dir. Elde edilen uyum ölçütleri, yapısal modelin en az kabul edilebilir düzeyde olduğunu göstermektedir. Şekil 2'de yer alan YEM sonuçlarına göre, özellikle hayvanların çıkarları ve hayvanların bulundukları ortam dikkate alındığında, hayvan odaklı turizm çekiciliklerinin kabul edilebilir bulunma düzeyi ile söz konusu çekiciliklere yönelik alg1 azalmaktadır. Diğer bir ifadeyle hipotezlerin tamamı kabul edilmiş olup, bilimsel araştırma ha- riç $t$ değerlerinin negatif yönlü 0,30'un üzerinde olduğu YEM'de gösterilmektedir. Bu durum talep boyutunda hayvanların çıkarlarının ve bulundukları ortamların önemsendiği, ancak tam anlamıyla hayvanlara yönelik bir ahlaki statünün de var olmadığ 1 şeklinde bir çıkarımı işaret etmektedir.

\section{SONUÇ VE TARTIŞMA}

Çalışmanın çıkış noktası olan ve felsefi zeminde giriş kısmında belirtilen "Hayvan odaklı turizm faaliyetine katılmanın ya da bu faaliyetler içerisindeki zevk ve tercihlerin ahlaki yükü, hayvanların metalaştırılması karşısındaki ahlaki yüke ağır $\mathrm{m}$ basıyor? temel sorusu yeniden düşünüldüğünde, çalışmanın kümülatif olarak bu soruya verdiği yanıt hem felsefi tartışmalar hem de elde edilen sonuçlar neticesinde büyük ölçüde evet yönündedir. Nitekim hem talep hem de arz boyutunda ortaya çıkan araştırma bulguları hayvanların birer turistik çekicilikten ibaret olduklarını (talep boyutu) ve birer meta olarak görüldüğünü (arz boyutu) göstermektedir. Az sayıda da olsa, uluslararası yazında turizm-hayvan etiği bağlamında yapılan çalışmalar da söz konusu soruya ilişkin benzer cevaplar vermektedir (Hughes 2001; Ballantyne vd. 2007; Cohen 2009; Linke and Winter 2011; Fennell 2011; 2012; Fennell 2013 Markwell 2015). Örneğin Linke ve Winter'ın (2011) hayvanat bahçelerini ziyaret edenler üzerinde yaptıkları çalışmada, ziyaretçilerin hayvanat bahçelerini ziyaret etmelerinin temel nedeninin "eğlence" olduğu sonucuna varılmıştır. Yine Cloke ve Perkins'in Yeni Zelanda'da yaptıkları çalışmada (2005), katılımcıların yunusları görmek ve onlar ile yüzmenin eşsiz bir deneyim olduğu yönündeki düşüncelerinin eğlence boyutu ile ilgili olduğu ifade edilmektedir. Fennell (2011, 2012, 2013) ise turizm sektöründe hayvanların yaşamın birer öznesi olarak görülmediğinden dolayı hayvanların eğlence, eğitim ya da deneyim temelinde metalaştırıldığını vurgulamaktadır. Fennell'ın ifade etmiş olduğu durum aslında hayvan etiği teorisyenlerinin ifade ettikleri ile paralellik göstermektedir (Singer 2002; Regan 2007; Francione 2008). Nitekim Singer, Regan ve Francione sırasıyla hayvanların acı çekip çekmemesi, 


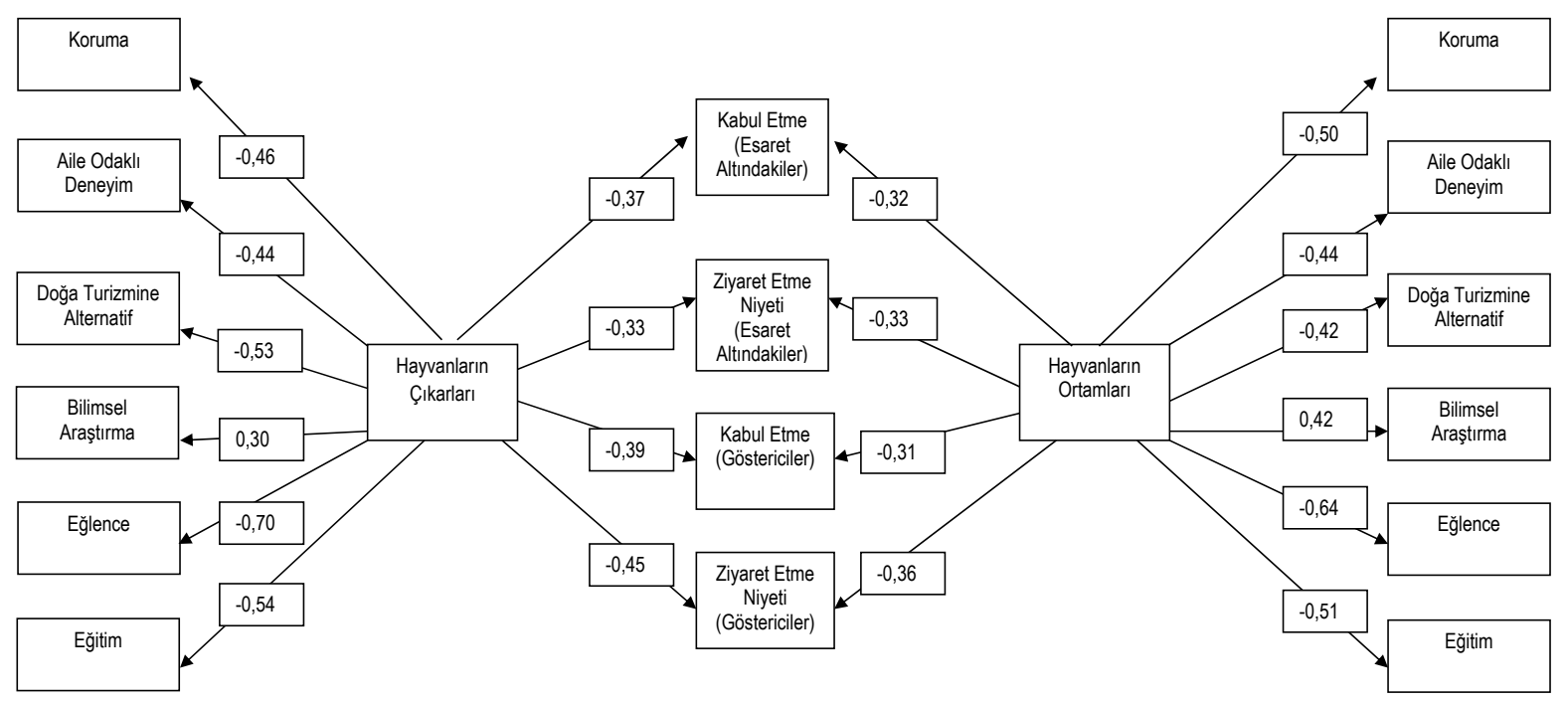

Şekil 1. Talep Boyutunda Hayvan Odaklı Turizm Faaliyetlerine Yönelik YEM Modeli- T Değerleri

yaşamın öznesi olarak var olma ya da eşit gözetilme ilkesinden yola çıkarak hayvanların da insanlar gibi ahlaki bir statülerinin olması gerekliliğini savunmaktadırlar. Dolayısıyla insan-hayvan etkileşiminin yoğun olduğu turizm sektöründe de hayvanlara yönelik yapılacak meta eleştirel yaklaşımın temelinde bu felsefi teoriler yatmaktadir.

İşletmeler, hayvanlar, ziyaretçiler, devlet politikaları, sivil toplum kuruluşları ve toplumun kendisi hayvan odaklı yaratılan turizm çekiciliklerinde rol oynayan aktörler şeklinde sıralanmaktadır. Bu aktörler içerisinde tek yasal hakkı olmayanlar ise metalaştırılan hayvanlardır. Ayrıca ister Singer'ın faydacı yaklaşımı açısından ister Francione' nin eşit gözetilme ilkesi açısından, ister Regan'ın yaşamın öznesi olma ilkesi açısından değerlendirilsin turizmde metalaşt1rılan hayvanların yasal hakkı olmadığı gibi ahlaki değeri de bulunmamaktadır. Öyle ki zaten ahlaki değerden yoksun bir canlının da yasal bir hakkının olabileceği düşünülemez. Diğer yandan ise hayvanların yasal haklarının olması ahlaki olarak değer görecekleri ya da ahlaki statü elde edebilecekleri anlamina da gelemez. Hem ahlaki statü hem de yasal hak birbirinden ayrılmadan, birbirlerinin fonksiyonları şeklinde ele alınmalıdır ki ancak bu sayede turizmde kullanılan hayvanların yalnızca birer meta olarak görülmele- rinin önüne geçilebilir. Bu da hayvan odaklı turizm işletmelerinin dış çevresi kategorisi altında sözü edilen işletme - toplum, işletme - devlet ve işletme - STK ilişkilerinde hayvanlar lehine ortaya çıkabilecek bir tutum ile mümkün olabilir. Söz konusu bu tutumda daha önceki bölümlerde de belirtildiği gibi hayvan odaklı turizm talebini yaratan ziyaretçiler üzerinde etkili olarak hayvan odaklı turizm arzının değişimine ya da dönüşümüne neden olabilecektir. Bu bağlamda, hayvan hakları örgütlerinin (STK'lar) hayvan özgürleşmesi, hayvanların ahlaki statüsü yönünde yapacağ faaliyetler toplumsal farkındalığı artırarak devlet mekanizmalarının işleyişinde yani yasaları yapanlar üzerinde baskı yaratacaktır. Bu olumlu baskı devletin de hayvanları koruma yasası yerine onları duyguları olan birer canlı varlık olarak kabul etmesini ve hayvan hakları yasasının çıkarılması konusunda adım atmasını sağlayacaktır. Bu durum, hem artan toplumsal farkındalık sayesinde hayvanların da ahlaki statülerinin olması gerektiğini gösterecek hem de ahlaki statülerinin olması gerekliliği yasal haklarının da olmasının önünü açacaktır. Böylelikle hayvanların turizmde yalnızca birer meta olarak görülmesinin de meşru zemini ortadan kalkacaktır. Aksi takdirde, Smith ve Duffy'nin ifadesi ile turizm ahlakı dahi satın almaya çalışan bir endüstriden öteye geçemez (Holden 2004). 


\section{KAYNAKÇA}

Ballantyne, R., Packer, J., Hughes, K. ve Dierking, L. (2007). Conservation Learning in Wildlife Tourism Settings: Lessons From Research in Zoos And Aquariums, Environmental Education Research, 13 (3): 367-383.

Beardsworth, A. ve Bryman, A. (2001). The Wild Animal in Late Modernity: The Case of The Disneyization of Zoos, Tourist Studies, 1 (1): 83-104.

Bulbeck, C. (1999). The Nature Dispositions of Visitors to Animal Encounter Sites in Australia and New Zealand, The Journal of Sociology, 35 (2): 129-148.

Cloke, P. ve Perkins, H. C. (2005). Cetacean Performance and Tourism in Kaikoura, New Zealand, Environment and Planning D: Society and Space, 23 (6): 903-924.

Cohen, E. (2009). The Wild and The Humanized: Animals in Thai Tourism. Anatolia: An International Journal of Tourism and Hospitality Research, 20 (1): 100-118.

Fennell, D. A. (2011). Tourism and Animal Ethics. New York: Routledge.

Fennell, D. A. (2012). Tourism and Animal Right, Tourism Recreation Research, 37 (2): 157-166.

Fennell, D. A. (2013). Tourism and Animal Welfare, Tourism Recreation Research, 38 (3): 325-340.

Fennell, D. A. (2015). The Status of Animal Ethics Research in Tourism: A Review of Theory. İçinde; Kevin Markwell (Editör) Animals and Tourism: Understanding Diverse Relationship (ss. 27-43), Londra: Channel View Yayınları.

Francione, G. L. (2008). Hayvan Haklarma Giriș: Çосй̆unuz mu Köpeğiniz mi? (Çev. Renan Akman ve Elçin Gen). İstanbul: İletişim Yayınları.

Hall, D. R. ve Brown, F. (2006). Tourism And Welfare: Ethics, Responsibility And Sustained Well-Being. Londra: CABI.

Hall, D., Roberts, L., Wemelsfelder, F. ve Farish, M. (2003). Animal Attractions, Welfare and The Rural Experi- ence Economy. İçinde; Derek Hall ve Morag Mitchell (Editörler) New Directions in Rural Tourism (ss. 90-101). Londra: Ashgate.

Holden, A. (2004). Tourism Studies and The Social Sciences. Londra: Routledge.

Hughes, P. (2001). Animals, Values and Tourism-Structural Shifts in UK Dolphin Tourism Provision, Tourism Management, 22 (4): 321-329.

Kline, R. B. (2015). Principles and Practice of Structural Equation Modeling (4. Baskı). New York: Guildford Yayınları.

Krejcie, R. V. ve Morgan, D. W. (1970). Determining Sample Size For Research Activities, Educational and Psychological Measurement, 30 (3): 607-610.

Linke, S. ve Winter, C. (2011). Conservation, Education or Entertainment: What Really Matters to Zoo Visitors?, İçinde; Warwick Frost (Editör) Zoos and Tourism (ss. 6981). New York, Channel View Yayınları.

Markwell, K. (Ed.) (2015). Animals and Tourism: Understanding Diverse Relationships. Londra: Channel View Yayınları.

Regan, T. (2007). Kafesler Boşalsın: Hayvan Haklarıyla Yüzleşmek (Çev. Serpil Çağlayan). İstanbul: İletişim Yayınları.

Sekaran, U. ve Bougie, R. J. (2016). Research Methods For Business: A Skill Building Approach. New York: John Wiley \& Sons.

Shani, A. (2009). Tourists' Attitudes Toward The Use of Animals in Tourist Attractions: And Empirical Investigation (Basılmamıs Doktora Tezi). Department of Educational Research, Technology, and Leadership in the College of Education, Orlando: University of Central Florida.

Singer, P. (2002). Hayvan Özgürleşmesi (Çev. Hayrullah Doğan). İstanbul: Ayrıntı Yayınları.

Thompson, S. C. G. ve Barton, M. A. (1994). Ecocentric and Anthropocentric Attitudes Toward The Environment, Journal of Environmental Psychology, 14 (2): 149-157.

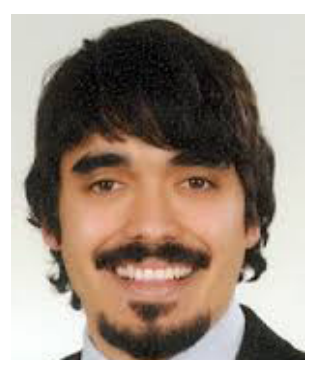

\section{S. Emre DILLEK}

Çanakkale Onsekiz Mart Üniversitesi Turizm İşletmeciliği ve Otelcilik Yüksekokulu Seyahat İşletmeciliği Bölümü'nden 2009 yılında mezun oldu. Yüksek lisans derecesini Çanakkale Onsekiz Mart Üniversitesi SBE Turizm İşletmeciliği Anabilim dalından 2012 yılında, doktora derecesini de Dokuz Eylül Üniversitesi SBE Turizm İşletmeciliği Anabilim dalından 2016 yılında aldı. 2012 yllından itibaren Batman Üniversitesi'nde çalışmaya başladı. Halen Batman Üniversitesi Turizm İşletmeciliği ve Otelcilik Yüksekokulu'nda görev yapmaktadır. Temel çalışma alanları turizm ve hayvan etiği, turizm sosyolojisi, sürdürülebilir turizm ve yeşil pazarlamadır.

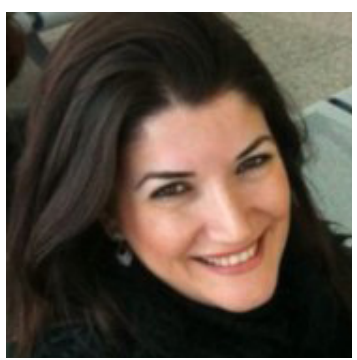

Ebru GÜNLÜ-KÜÇÜKALTAN

Dokuz Eylül Üniversitesi İşletme Fakültesi Turizm İşletmeciliği Bölümü'nden 1998 yılında mezun oldu. Yüksek lisans derecesini Dokuz Eylül Üniversitesi SBE Turizm İşletmeciliği Anabilim dalından 2000 yılında, doktora derecesini de Dokuz Eylül Üniversitesi SBE Turizm İşletmeciliği Anabilim dalından 2003 yılında aldı. Dokuz Eylül Üniversitesi'nde çalışmaya başladı. Doçentlik unvanını Yönetim ve Organizasyon alanında 2011 yılında aldı. Profesörlüğe Dokuz Eylül Üniversitesi'nde 2016 yılında yükseltildi. Halen Dokuz Eylül Üniversitesi İşletme Fakültesi'nde görev yapmaktadır. Temel çalışma alanları insan kaynakları yönetimi, yönetim ve organizasyon, stratejik yönetim ve turizm sosyolojisidir. 